\title{
Definitely Agree
}

National Cancer Institute

\section{Source}

National Cancer Institute. Definitely Agree. NCI Thesaurus. Code C103806.

An unequivocal feeling of concurrence. 